\title{
Impact of Climate Change on Budget Balance: Implications for Fiscal Policy in the ECOWAS Region
}

\author{
Binta Yahaya ${ }^{1}$, Louis Sevitenyi Nkwatoh ${ }^{1} \&$ Babagana Adamu Jajere $^{1}$ \\ ${ }^{1}$ Department of Economics, Yobe State Unversity, Nigeria \\ Correspondence: Louis Sevitenyi Nkwatoh, Department of Economics, Yobe State Unversity, Nigeria. E-mail: \\ sevinkwatoh@gmail.com
}

Received: May 22, 2021

Accepted: June 21, 2021

Online Published: July 8, 2021

doi:10.5539/ijef.v13n8p25

URL: https://doi.org/10.5539/ijef.v13n8p25

\begin{abstract}
The budget deficits of the Economic Community of West African States (ECOWAS) have been widening over the years. This study investigated the impact of climate change on budget balance and projected its implication for fiscal policy in ECOWAS countries. The two-step dynamic GMM method was applied for a balanced panel data of 14 countries from 2008 to 2018 . The study found that rainfall is the only climate variable that increases budget deficits. Other macroeconomic variables: debt to GDP ratio and inflation were also responsible for the widening budget deficits. A major policy implication of this finding is that extreme and unpredictable rainfalls will distort the fiscal balance of ECOWAS countries by either reducing the revenue generation outlets or by raising expenditures. This will lead to more borrowing that will further widen the existing budget deficits through debt servicing, hence, making the respective governments to pay less attention on other sectors of the economy. Thus, ECOWAS countries need to expand their revenue generation sources either by creating an enabling environment for more businesses and investments to strive or by engaging in more foreign direct investment (FDI).
\end{abstract}

Keywords: climate change, budget balance, fiscal policy

JEL Classification: C23, Q54, H62, H89.

\section{Introduction}

West African Economies just like any other economy in the World are keen about the sustainability of their public finances, and always strive to maintain a balance between tax revenues and public expenditures. This implies that a sound fiscal policy will always result into higher levels of capital spending and employment, which will in turn, create a virtuous cycle of economic prosperity. However, unexpected circumstances often increase government expenditure. One of such circumstances is the occurrence of unexpected extreme climate conditions that increases government expenditure and reduces the volume of tax revenues, thereby leading to a possible increase in government debts. According to Perry and Ciscar (2014), climate change impacts often increase public expenditures through disaster relief payments to households or reconstruction of infrastructure. An empirical study by Baarsch et al. (2011) reveals that high-warming scenarios in Eastern and Western Africa, will reduce their GDP per capita by approximately 15 percent by 2050 . Thus, higher climate-induced expenditures will reduce tax revenue and create a budget imbalance, thereby, reducing the budget allocations for other public sectors' activities.

The literature on the impact of climate change on government budget, and its implication on fiscal policy is relatively new. The few studies in this area points to the fact that negative climatic effects widen the budget deficits of many economies around the world. For instance, Jones, Keen, and Strand (2012) submitted that a high cost is always incurred when mitigating the effect of climate change on public revenue; Lis and Nickel (2009) concluded that extreme weather conditions create negative impacts on the budget balance of developed and developing economies; Bachner and Bednar-Friedl (2018) showed that climate change impacts have multiple negative effects on public budgets.

Fiscal sustainability and austerity measures are fiscal tools that determine the national budget of many countries across the world. However, the impact of extreme climate may lead to higher public expenditures (Perry \& Ciscar, 2014), causing a deficit financing (Bachner \& Bednar-Friedl, 2019).

The Economic Community of West African States (ECOWAS) through various Agreements and Treaties desire to 
strengthen regional integration and promote regional growth. One of the requisite conditions for a deeper regional integration is trade among member countries. Recently, Chucku (2012) observed that there is weak inter-demand among ECOWAS countries. This may be attributed to the fact that production is responding negatively to climatic conditions. Changes in climatic conditions have unexpectedly increased the expenditure of ECOWAS countries, most often via extra-budgetary expenditure, thereby, creating an imbalance in public budgets. This imbalance has an overall negative effect on the fiscal structure of member countries and on the regional economic growth of ECOWAS. Therefore, the objective of this study was to investigate the impact of climatic change on the budget balance of ECOWAS economies and to project its implication for fiscal policy in the ECOWAS region.

The article is structured as follows: section 1 presents the introduction; section 2 ushers in the literature review; section 3 advances the methodology; section 4 reports the results, while section 5 presents the conclusion and recommendations.

\section{Literature Review}

The mitigating effect of climate change on public budgets has been extensively discussed in literature. However, the effect of climate change and its implication for fiscal policy is relatively new. Hochrainer-Stigler, Mechler, Pflug and Williges (2014) assessed the vulnerability of public finance to disaster risks and whether the mitigation effect on the affected population of developing countries could be achieved through disaster relief payments. They concluded that many countries are fiscal-vulnerable and required assistance from donor communities in order to bolster their fiscal resilience. Cummins and Mahul (2009) had earlier pointed out that interventions from donors and International Financial Institutions (IFIs) should be used in developing affordable, effective and sustainable country-specific catastrophe programs.

Few studies have examined the effect of climate change-impacts on government budgets. Early estimates by the World Bank (2010) included investment requirements for public sectors. In line with the above study, Osberghaus and Reif (2010) provided a back-of-the envelope estimates for the direct costs of climate change on public budgets in the European Union. Lis and Nickel (2010) used data from extreme events database to estimate the impact of extreme events on the changes in the budget balance for a panel of 138 countries. Leppänen, Solanko, and Kosonen (2015) estimated the effects of changes in climatic conditions on the Russian regional governments' expenditures from 1999-2005 and found a comparatively small and positive budgetary effect due to higher temperatures (milder winters). Delpiazzo, Parrado, and Bosello (2015) investigated the budgetary implications of sea-level rise and adaptation in terms of changes in the public deficits of Least Developed Countries. They concluded that coastal protection was beneficial for developing countries, even though it required additional expenditures that worsen public deficits.

A handful of studies have investigated the fiscal implications of natural disasters resulting from extreme weather conditions. For instance, Schuknecht (1999) arrived at a significant and negative effect of catastrophes on fiscal balance after estimating a fixed effect model for 25 developing countries. Benson and Clay (2004) provided evidence of severe negative short-run economic impacts caused by major natural disasters, which also appear to have long run consequences on economic growth, development, and poverty reduction in Bangladesh. Heipertz and Nickel (2008) concluded that climate change increased the number and severity of disasters, affecting the budget balance of EU countries and the US. Similar results were obtained by Deryugina (2016) indicating that disaster-related public expenditures affected the budget balance of US in relatively small proportions. In a related study, Alejos (2017) concluded that the occurrence of at least one extreme weather event is associated with an increase in the budget deficit of 169 countries selected arbitrarily.

\section{Methodology and Source of Data}

This section describes the sample, variables used in the econometric models and the estimation technique.

\subsection{Data}

A panel of 14 ECOWAS countries was constituted based on the availability of secondary data and covered the period between 2010 and 2018. Incidentally, this period coincides with the much talk about global warming, suggesting a threat of climate change to socio-economic activities. Data for the different variables were extracted from World Bank Development Indicators published by the World Bank and WAMA indicators published by the West African Monetary Agency. The variables include: budget deficit (BDF), which is a proxy to budget balance; temperature (TEMP); rainfall (RAINF); one-year lag of debt to GDP ratio $\left(\triangle \mathrm{DebtGDPR}_{\mathrm{t}-1}\right)$; annual GDP growth (AGDP) and inflation (INF).

\subsection{Model Specification and Estimation Technique}

Building on Andres and Vallelado (2008) and Sanda et al. (2005), we specify two models establishing the link 
between climate change variables and budget deficit as follows:

$$
\begin{gathered}
B D S_{i, t}=\beta_{0} \pm \beta_{1} \text { RAINF }_{i, t} \pm \beta_{2} \Delta \text { Debt }_{i t} \pm \beta_{3} R G D P_{i, t} \pm \beta_{4} \text { Inflation }_{i, t} \pm \beta_{5} \text { GOVE }_{i, t} \pm \delta_{t} \pm \gamma_{t} \pm \mu_{i, t} \\
B D S_{i, t}=\beta_{0} \pm \beta_{1} \text { TEMPP }_{i, t} \pm \beta_{2} \Delta \text { Debt }_{i t} \pm \beta_{3} R G D P_{i, t} \pm \beta_{4} \text { Inflation }_{i, t} \pm \delta_{t} \pm \gamma_{t} \pm \mu_{i, t}
\end{gathered}
$$

All the variables in equations (1) and (2) are defined already, and the i's represent country 1 through 196 . The $t$ represents values for the years from 2010 to 2018. The $\beta$ parameters are the constant terms and the estimated coefficients for their respective models. The error term is split into three components: $\delta_{t}$ is the time effect, which controls for macroeconomic shocks, $\gamma_{t}$ is the individual effect, which controls for unobservable heterogeneity and $\mu_{i, t}$ is the stochastic disturbance.

We adopted the panel data analysis technique because of the pooled nature of the data set (mixture of time series and cross section) and its ability to take into account the unobservable and constant heterogeneity effects inherent in a data set. Instrumental variables were introduced to resolve the problem of endogeneity (see, Wooldridge, 2002). Thus, we adopted Arellano \& Bond's (1998) two-step system system estimator with adjusted standard errors for potential heteroskedasticity. The itinerary of this method considers the unobservable effects, transforming the variables into first difference and using the generalized method of moments (GMM) with instrumental variables to deal with endogeneity problems (see. Kama1 \& Chuku).

We used the lags of TEMP, Rainfall, Debt-to-GDP ratio, Inflation and ARGDP as instrumental variables. The J-statistic was employed to test for over identification of restrictions and to examine the correlation between the instruments and the error term.

\section{Results and Analysis}

Table 1 presents the estimated results of the two models. The diagnostic tests show that the models are well fitted and unbiased. The J-statistic asserts the suitability of the instrumental variables, which resolved the problem of endogeneity. The first and second-order serial correlation tests show that the two models are void of serial correlation, while the F-test confirmed the overall fitness of the model.

All the macroeconomic variables used in models $1 \& 2$ have the expected signs, but only significant for model 1 , when RAINFALL is included in the estimation. This implies that extreme temperatures don't pose a problem to the budget deficits of ECOAWS Countries. Hence, only the results including rainfall are reported.

Model 1, shows that the current year's budget deficits of ECOWAS countries significantly depends on the previous year's deficits. That is an increase in the budget deficit in the previous year leads to an increase in the budget deficit in the current year by approximately $0.11 \%$ of the GDP in ECOWAS. This may be due to the accumulated deficits over the years, which often affect the current deficits of member countries, whose revenue generation is less - expenditure.

The lagged change in the debt to GDP ratio and budget deficit have a significant and positive sign, implying that the budget deficit of ECOWAS countries will increase by approximately $7.96 \%$ with an increase in the debt to GDP ratio. This result is plausible because the interest rate on servicing both domestic and external debts have increased over the years. According to Peter (2017) cited in Amdeo (2020), higher debt levels make it difficult to raise funds because creditors demand higher interest rates that provide a greater return on a higher risk of non-payment of debts. In line with this submission, Tujula and Wolswijk (2004) had earlier discovered that debt growth and budget balance exhibit a positive relationship in the OECD region; likewise, Folorunso and Falade (2013) who got similar results in Nigeria. All these findings are in conformity with the finding of this study.

Annual GDP growth rate significantly reduces the budget deficit of ECOWAS countries by approximately $9.54 \%$. This finding is in conformity with Pettinger's (2019) submission that more revenues are generated from taxes, which ultimately reduces budget deficit. This finding is in line with that of Mansoor, Emamib and Salimi (2016) in the Mena.

Inflation and budget deficit have a positive and significant relationship. That is an increase in inflation rate will cause an increase in the budget deficit of ECOWAS countries by approximately 17.07\%. This result is expected because high inflation raises spending. This result is line with the findings of (Saba, 2015; Orji, Onyeze, \& Edeh, 2014; Baradaran, Asgharpur, Panahi, Kazerooni, \& Alireza, 2017; and Lis \& Nickel, 2009) for developing, OECD and EU countries.

Lastly, extreme rainfalls significantly increase budget deficit by $5.52 \%$. This mostly takes place via extra-budgetary expenditure in the form of relief and rebuilding of infrastructure. This in line with Alejos's (2017) study who discovered that the occurrence of at least one extreme weather event is associated with an increase in the budget deficit of between $0.4 \%$ and $0.9 \%$ of the GDP for a panel of 168 selected countries. Similar findings 
had been obtained by (Lis \& Nickel, 2009) for developing, OECD and EU countries.

Table 1. Estimated relationship between budget deficit and rainfall in ECOWAS

\begin{tabular}{cccccc}
\hline & \multicolumn{2}{c}{ Model 1: BDEF } & \multicolumn{2}{c}{ Model 2: BDEF } \\
& Estimation with Rainfall (RAIN) & Estimation with Temperature (TEMP) \\
\hline Independent Variables & Coefficient & $\mathrm{P}>|\mathrm{t}|$ & Independent Variables & Coefficient & $\mathrm{P}>|\mathrm{t}|$ \\
\hline BDEF (-1) & 0.1137 & $0.000^{* *}$ & BDEF (-1) & 0.5898 & 0.3238 \\
RAINFALL & 17.4039 & $0.0001^{* *}$ & TEMP & 6.1543 & 0.0756 \\
AGDPGR & -9.5377 & $0.0001^{* *}$ & AGDPR & -8.7402 & 0.0431 \\
DEEBTGDPR(-1) & 7.9605 & $0.0321^{* *}$ & $\Delta$ DEBTGDPR(-1) & 10.0861 & 0.4483 \\
INF & 5.5237 & $0.0001^{* *}$ & INF & 1.3260 & 0.9635 \\
F & 17.064 & $0.000^{* *}$ & F & & \\
J & 6.7 & 0.0667 & J & 6.8426 & 0.6535 \\
AR(1) & -0.9988 & 0.3178 & AR(1) & -0.2015 & 0.7352 \\
AR(2) & -0.9975 & 0.3185 & AR(2) & -0.2148 & 0.8299 \\
\hline
\end{tabular}

Source: Authors' computation using Eviews.

\section{Policy Implication}

The study has revealed that the only climate variable that increases the budget deficit of ECOWAS countries is rainfall. It is observed that extreme rainfall affects both the revenue and expenditure of most countries. It mostly affects spending in the form of relief, reconstruction and building of infrastructure via extra budgetary expenditure. First and foremost, extreme rainfall patterns are unpredictable, hence spending on rainfall related issues are unpredictable as well. This implies that extreme and unpredictable rainfall will distort the budget balance of ECOWAS countries by either reducing their revenue generation outlets or by raising their spending capacities. Reducing revenue generation outlets and raising expenditure will force most ECOWAS countries to borrow either from domestic or external sources in order to meet up with their current and future expenses. This will further widen the existing deficits because debt servicing requires high interest rates, which will in turn force ECOWAS countries to pay less attention on other sectors of the economy.

\section{Conclusion}

Climate change has an effect on budget balance due to extreme rainfall, which is partly responsible for large budget deficits via extra budgetary expenditure. This study investigated the impact of climate change on budget deficit using two climate variables - rainfall and temperature, and projected its implication for fiscal policy in ECOWAS countries. The two-step dynamic GMM method was applied for a balanced panel data of 14 countries from 2008 to 2018. The study concluded that only extreme rainfall is responsible for the widening budget deficits of ECOWAS countries. This finding is in conformity with the findings in the literature. Therefore, ECOWAS governments need to expand their domestic and external sources of revenue generation. External source can be in the form foreign direct investment (FDI) while domestic sources can be through creating an enabling environment for businesses and investments to strive, and also by encouraging the growth of small and medium scale size enterprises (SMEs). All these will increase the tax revenues of the respective countries, hence reducing their budget deficits.

Respective governments should engage researchers and especially econometricians to use predictive models like time series analysis (ARIMA models) to project rainfall patterns before the start of each budgetary year. This will give policy makers a first-hand information on the nature of rainfall before the budget is passed by their respective national assemblies. This lead will to proper resource allocation/expenditure on rainfall related issues.

\section{References}

Alejo, L. (2017). Estimating the fiscal impact of extreme weather events. Retrieved from http://www-personal.umich.edu/ lalejos/pdf/FiscalImpact.pdf

Amadeo, K. (2020). Budget Deficits and How to Reduce Them: Causes and Effects. Retrieved from https://www.thebalance.com/budget-deficit-definition-and-how-it-affects-the-economy-3305820\#citation-1 4

Andres, P., \& Vallelado, E. (2008). Corporate Governance in Banking: The Role of the Board of Directors. Journal of Banking and Finance, 2570-2580. https://doi.org/10.1016/j.jbankfin.2008.05.008 
Arellano, M., \& Bond, S. (1998). Dynamic Panel Estimation Using DPD98 for GAUSS: A Guide for Users. Working Paper, Institute for Fiscal Studies.Retrieved from http://www.cemfi.es/ arellano/\#dpd

Baarsch et al. (2011). Economic growth, development and climate change in Africa. African Climate Policy Centre. Retrieved

from https://archive.uneca.org/sites/default/files/uploaded-documents/ACPC/annex_21b_-_climate_change_impa cts_on_africas_economic_growth_-_report.pdf

Bachner, G., \& Bednar-Friedl, B. (2019). The Effects of Climate Change Impacts on Public Budgets and Implications of Fiscal Counterbalancing Instruments. Environ Model Assess, 24(4), 121-142. https://doi.org/10.1007/s10666-018-9617-3

Baradaran, K., Asgharpur, Z., Panahi, H., \& Kazerooni, A. (2017). The Asymmetric Effect of Inflation on the Budget Deficit in Iran. Quantile Regression Approach. Quarterly Journal of Applied Theories of Economics, 4(3), 169-194. https://doi.org/10.1016/j.econmod.2017.02.004

Chuku, C. (2012). The Proposed Eco: Should West Africa Proceed with a Common Currency? Paper presented at the Centre for the Study of African Economies (CSAE) 2012 Conference on "Economic Development in Africa", Oxford University, Oxford 18-20.

Cummins, J. D., \& Mahul, O. (2009). Catastrophe Risk Financing in Developing Countries: Principles for Public Intervention. Washington, DC: World Bank. https://doi.org/10.1596/978-0-8213-7736-9

Delpiazzo, E., Parrado, R., \& Bosello, F. (2015). Analyzing the coordinated impacts of climate policies for financing adaptation and development actions (No. RP0276). CMCC. Retrieved from https://www.gtap.agecon.purdue.edu/resources/download/7978.pdf

Deryugina, T. (2016). The Fiscal Cost of Hurricanes: Disaster Aid Versus Social Insurance. NBER Working Paper No. 22272. https://doi.org/10.3386/w22272

Folorunso, A., \& Falade, O. (2013). Relationship between Fiscal Deficit and Public Debt in Nigeria: An Error Correction Approach. Journal of Economics and Behavioural Studies AMH International, 5(6), 346-355. https://doi.org/10.22610/jebs.v5i6.410

Guess, G., \& Koford, K. (1986). Inflation, recession and the federal budget deficit (or, blaming economic problems on a statistical mirage). Policy Sciences, 17, 385-402. https://doi.org/10.1007/BF00138402

Hermalin, B., \& Weisbach, M. (2003). Board of Directors as an Endogeniously Determined Institution: A Survey of Economic Litrature. FRBNY Economic Policy Review, 9(1), 7-26.

Hochrainer-Stigler, S., Mechler, R., Pflug, G., \& Williges, K. (2014). Funding public adaptation to climate-related disasters. Estimates for a global fund. Global Environmental Change, 25, 87-96. https://doi.org/10.1016/j.gloenvcha.2014.01.011

Jones, B., Keen, J., \& Strand, M. (2012). Fiscal Implications of Climate Change. https://doi.org/10.1596/1813-9450-5956

Leppänen, S., Solanko, L., \& Kosonen, R. (2015). The impact of climate change on regional government expenditures: evidence from Russia. Environmental and Resource Economics, 67(1), 67-92. https://doi.org/10.1007/s10640-015-9977-y

Lis, M., \& Nickel, C. (2010). The impact of extreme weather events on budget balances. International Tax and Public Finance, 17(4), 378-399. https://doi.org/10.1007/s10797-010-9144-x

Mansoor, A., Emami, K., \& Salimi, F. (2016). Growth and Productivity; the role of budget deficit in the MENA selected countries. Procedia Economics and Finance, 36, 345-352. https://doi.org/10.1016/S2212-5671(16)30046-6

Orji, U., Onyeze, N.,, \& Edeh, L. (2014). Inflation Dynamicsand Fiscal Deficitin Nigeria: Examination of Causal Relationship. IOSR Journal of Economics and Finance, 5(2), 79-86. https://doi.org/10.9790/5933-0527986

Osberghaus, D., \& Reif, C. (2010). Total costs and budgetary effects of adaptation to climate change: An assessment for the European Union. ZEW-Centre for European Economic Research Discussion Paper, (10-046), ZEW - Leibniz Centre for European Economic Research. https://doi.org/10.2139/ssrn.1649452

Perry, M., \& Ciscar, J. (2014). Multi-sectoral perspective in modelling of climate impacts and adaptation. In I. Galarraga, \& E. Sainz de-Murieta (Eds.), Routledge Handbook of the Economics of Climate Change Adaptation. London: Routledge. 
Pettinger, T. (2019). Policies to reduce a budget deficit. Retrieved from https://www.economicshelp.org/blog/6011/economics/policies-to-reduce-budget-deficit/

Sanda, A., Mikailu, A., \& Garba, T. (2005). Corporate Governance Mechanisms and Firm Financial Performance in Nigeria. African Economic Research Consortium, Research paper 149, Nairobi.

Schuknecht, L. (1999). Fiscal policy cycles and the exchange rate regime in developing countries. European Journal of Political Economy, 15, 569-580. https://doi.org/10.1016/S0176-2680(99)00025-7

Tujula, M., \& Wolswijk, G. (2004). What determines fiscal balances? An empirical investigation in determinants of Changes in OECD Budget Balances. Working Paper Seriesno. 422. Retrieved from http://www.ecb.int

WAMA. (2019). WAMA Indicators. Retrieved from https://amao-wama.org

Windmeijer, F. (2000) A Finite Sample Correction for the Variance of Linear Two-Step GMM Estimator. Journal of Econometrics, 126(1), 25-51. https://doi.org/10.1920/wp.ifs.2000.0019

Wooldridge, J. M. (2002). Econometric Analysis of Cross Section and Panel Data. Cambridge, M.A: MIT Press.

World Bank. (2010). The Cost to Developing Countries of Adapting to Climate Change: New Methods and Estimates (Consultation draft). World Bank.

World Bank. (2019). World Bank Development Indicators. Retrieved from https://data.worldbank.org/indicator.

\section{Copyrights}

Copyright for this article is retained by the author(s), with first publication rights granted to the journal.

This is an open-access article distributed under the terms and conditions of the Creative Commons Attribution license (http://creativecommons.org/licenses/by/4.0/). 